Iryna Kachkurkina, Valery Ovcharov, Oksana Okhtina and Olena Tertyshna

\title{
VULCANIZATION PECULIARITIES OF RUBBERS OF GENERAL AND SPECIAL PURPOSE IN THE PRESENCE OF ZINCCONTAINING POLYMER-INORGANIC COMPOSITE
}

\author{
State Higher Educational Institution «Ukrainian State Chemical Technological University» \\ 8 Gagarin's Av., 49005 Dnipropetrovsk, Ukraine \\ svoks@inbox.ru
}

Received: February 17, 2009

(C) Kachkurkina I., Ovcharov V., Okhtina O., Tertyshna O., 2009

\begin{abstract}
In this work the synthesis technology of zinccontaining polymer - inorganic composite on the basis of products of secondary raw material processing at joint precipitating with carbamide and formaldehyde ( $\mathrm{ZnCFO}$ ) is described. The structure and properties of $\mathrm{ZnCFO}$ are investigated by the differential-thermal analysis, electronic microscopy, and IR-spectroscopy. The action of ZnCFO as vulcanization active component of elastomeric compositions on the basis of rubbers of general and special purpose with various vulcanization systems is investigated. The $\mathrm{ZnCFO}$ influence on the character of the formed morphological structure of rubbers is determined by the method of percalation analysis.
\end{abstract}

Key words: zinccontaining polymer-inorganic composite, rubber, vulcanization, elastomeric composition, vulcanization activator, physico-mechanical properties, morphological structure.

\section{Introduction}

In spite of 150-year history of vulcanization process, it is impossible to consider that fundamental and applied researches in the direction of vulcanization systems improvement are complete. For today one of the ways of rubbers properties improvement is the synthesis and application of new chemicals-additives, including the vulcanization active ones. This is connected, first of all, with reduction of global zinc ores stock as basic raw material for production of the traditional activator - zinc oxide. Besides, modern increase of industrial potential which results in the accumulation of a large quantity of wastes cause a number of ecological problems that require emergency measures. Therefore creation of resource saving technologies of the new compounds reception from products of secondary raw material processing has gained paramount importance.

\section{Experimental}

In view of the above said this work offers the first investigation of the effectiveness of zinccontaining carbamide-formaldehyde composite ( $\mathrm{ZnCFO}$ ) as vulcanization active component of various vulcanization systems for rubbers of general and special purpose.

Structure and properties of the composite have been studied by means of instrumental analysis methods.

The electronic microscopy method using the EM-125 for definition of ZnCFO particles size and surface characteristic was applied. Known zinc oxides were chosen as the comparison object.

The definition of thermal stability of inorganic zinccontaining $\left(\mathrm{Zn}(\mathrm{OH})_{2}\right)$, organic carbamideformaldehyde (CFO) components, and $\mathrm{ZnCFO}$ composite was carried out by the method of differential-thermal analysis on the derivatograph "Q-1500 D" of F. Paulik, J. Paulik, L. Erdey system in the temperature range of $293-1273 \mathrm{~K}$ at the heating rate of $283 \mathrm{~K} / \mathrm{min}$ and the samples mass of $200 \mathrm{mg}$.

The study of $\mathrm{ZnCFO}$ was also carried out by the method of IR-spectroscopy on spectrometer UR-20.

The researches of ZnCFO compatibility with the matrix of isoprene rubber were carried out in plasticorder "Brabender" PLE 651.

An estimation of $\mathrm{ZnCFO}$ effectiveness as vulcanization active component was carried out in modelling unfilled elastomeric compositions on the basis of isoprene, butadiene-nitrile, chloroprene, and butyl rubbers of sulphur, thiuram, peroxide, metaloxide, and resin vulcanization systems.

The rubber compounds were mixed in a laboratory internal mixer, the tests of elastomeric compositions were carried out according to working techniques and requirements of state standard. 


\section{Results and Discussion}

The technological circuit of $\mathrm{ZnCFO}$ synthesis has been developed in the Ukrainian State ChemicalTechnological University. ZnCFO is the product of reaction of carbamide and formaldehyde polycondensation in zinc salts solution occurring at recycling of metal containing wastes of chemical manufactures of Ukraine. The material base of $\mathrm{ZnCFO}$ manufacture are dead catalysts, zincing solutions and other zinccontaining wastes of various origin.

The maximal degree of zinc extraction $\left(\varphi Z^{2+}\right)=$ 95-98\% and mass ratio of zinc hydroxide to carbamideformaldehyde component in the composite $\left(m_{\mathrm{Zn}(\mathrm{OH}) 2}: m_{\mathrm{CFO}}\right)=$ $=1: 0.7-1$ is achieved at the observance of the following technological parameters: temperature $(T)=298-308 \mathrm{~K}$; concentration of zinc salts in solution $\left(c_{Z_{n}}{ }^{2+}\right)=150$ $170 \mathrm{~g} / \mathrm{l} ; \mathrm{pH}$ of zinc salts solution $=2 ; \mathrm{pH}$ of the reactionary mix at complete precipitating $\mathrm{Zn}^{2+}=7-8 ; \mathrm{pH}$ of the reactionary mix at polycondensation $=3-5$; mole ratio of carbamide to formaldehyde $\left(n_{C}: n_{F}\right)=1: 1[1,2]$.

The electronic photos of powders (Fig. 1) show that the new composite and zinc oxide have external similarity by the form of particles, differ by dispersiveness (0.4-6.0 microns for zinc oxide, Fig. 1a; 0.3-6.0 microns for $\mathrm{ZnCFO}$, Fig. 1b) and contain both crystal and amorphous phases in their structure.

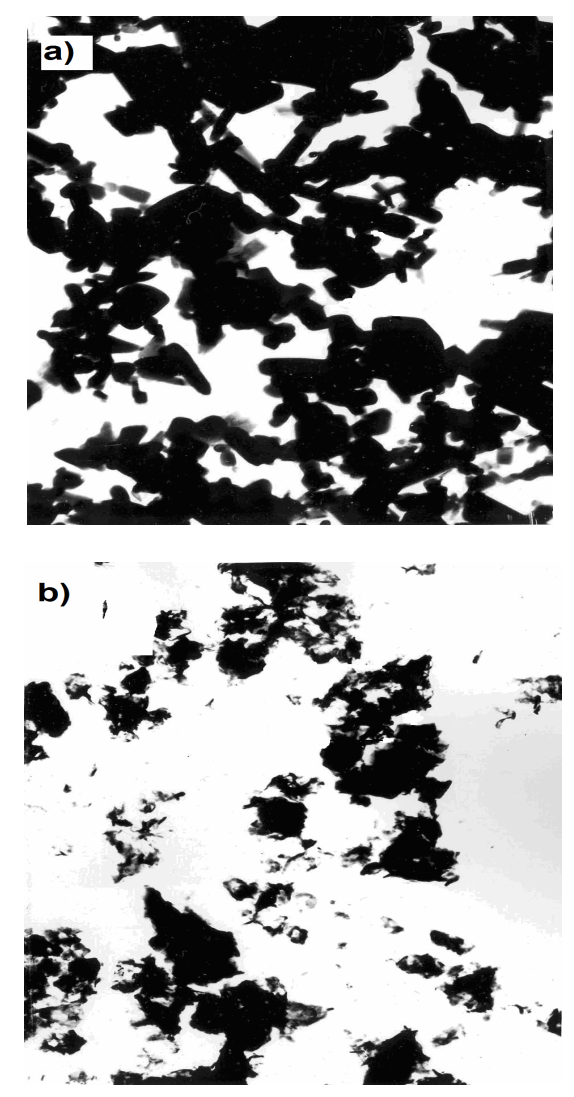

Fig. 1. EM micrographs of the $\mathrm{ZnO}$ (a) and $\mathrm{ZnCFO}$ (b) particles (increase in 10000 times)
DTA and TG curves of the researched products are presented in Fig. 2. As one can see, endothermic peak on DTA curve of $\mathrm{Zn}(\mathrm{OH})_{2}$ and the greatest loss of weight at $\mathrm{T} \approx 423-433 \mathrm{~K}$ are caused by transition of hydroxide into oxide. DTA curves of $\mathrm{CFO}$ and $\mathrm{ZnCFO}$ have external similarity by the character of the thermal effects, however, for $\mathrm{ZnCFO}$ the shift of maximums into the range of lower temperatures is observed. Thus, peaks at $\mathrm{T} \approx 363-373 \mathrm{~K}$ are caused by the loss of atmospheric moisture contained in the samples. Endothermic maximum and greatest loss of weight $(\approx 35 \%)$ in the temperature range $533-543 \mathrm{~K}$ characterize the beginning of CFO thermodestruction, and secondary exothermic peak at $\mathrm{T} \approx 833 \mathrm{~K}$ is caused by the subsequent decomposition of the sample. Unlike CFO on DTA curve of $\mathrm{ZnCFO}$ the first endothermic maximum is observed at $T \approx 443-453 \mathrm{~K}$, and secondary exothermic maximum - at $\mathrm{T} \approx 723-733 \mathrm{~K}$, which is characteristic of organic component decomposition. Appearance of a new endothermic peak at approximately $1083 \mathrm{~K}$ indicates expansion of the temperature range of $\mathrm{ZnCFO}$ destruction process in comparison with $\mathrm{CFO}$, while the temperature interval of weight loss for CFO is $533-833 \mathrm{~K}$, and for $\mathrm{ZnCFO}-443-1083 \mathrm{~K}$, and $\mathrm{ZnCFO}$ has extremely greater mass residue. It is necessary to note that $\mathrm{ZnCFO}$ at thermal action is decomposed not reaching a melting point, which was confirmed by the method of capillary melting temperature definition [3,4]. During the experiment an intensive gas release and change in sample color from white to grey at the temperatures $443 \mathrm{~K}$ and $493 \mathrm{~K}$ that correspond to the first endothermic peak on DTA curve, were visually observed.

For detection of possible chemical bonds between inorganic and organic components in $\mathrm{ZnCFO}$ the spectra of $\mathrm{Zn}(\mathrm{OH})_{2}$, CFO and $\mathrm{ZnCFO}$ were studied (Fig. 3). As can be seen, IR-spectrum of $\mathrm{ZnCFO}$ the characteristic $\mathrm{CFO}$ absorption bands repeat at 3350,1640 , and $1550 \mathrm{~cm}^{-1}$, caused by the presence of a secondary amide group [5]; at the same time the intensity of absorption band in the range $2340-2360 \mathrm{~cm}^{-1}$, identifying $\mathrm{R}_{2} \mathrm{C}=\mathrm{N}_{\text {group, }}^{+}$ is considerably decreased [6]. In comparison with IRspectrum of $\mathrm{Zn}(\mathrm{OH})_{2}$, on $\mathrm{ZnCFO}$ spectrum the intensity of characteristic absorption band at $1384 \mathrm{~cm}^{-1}$ decreased. The distinctive feature of $\mathrm{ZnCFO}$ spectrum is the presence of absorption band at $1120 \mathrm{~cm}^{-1}$, which probably corresponds to bonds (e.g. coordination ones) between inorganic and organic components of the composite. It can be assumed, that the coordination bonds in the composite arise between nitrogen atom of $\mathrm{R}_{2} \mathrm{C}=\stackrel{+}{\mathrm{N}}-\mathrm{H}$ group and zinc atom in $\mathrm{Zn}(\mathrm{OH})_{2}$.

The estimation of ZnCFO compatibility with the rubber matrix have shown that the composite dispersion process is accompanied by lower power consumption and 

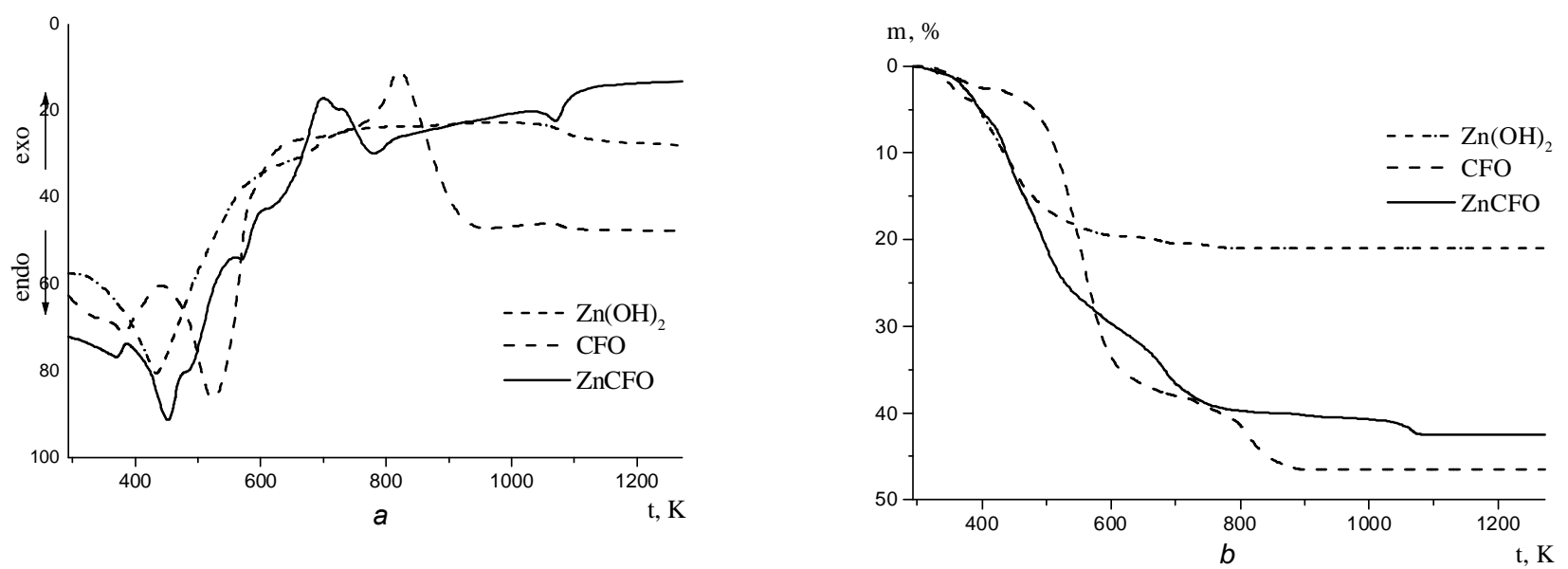

Fig. 2. Results of derivatographic researches of $\mathrm{Zn}(\mathrm{OH})_{2}$, CFO and $\mathrm{ZnCFO}$ : DTA curves (a) and TG curves (b)
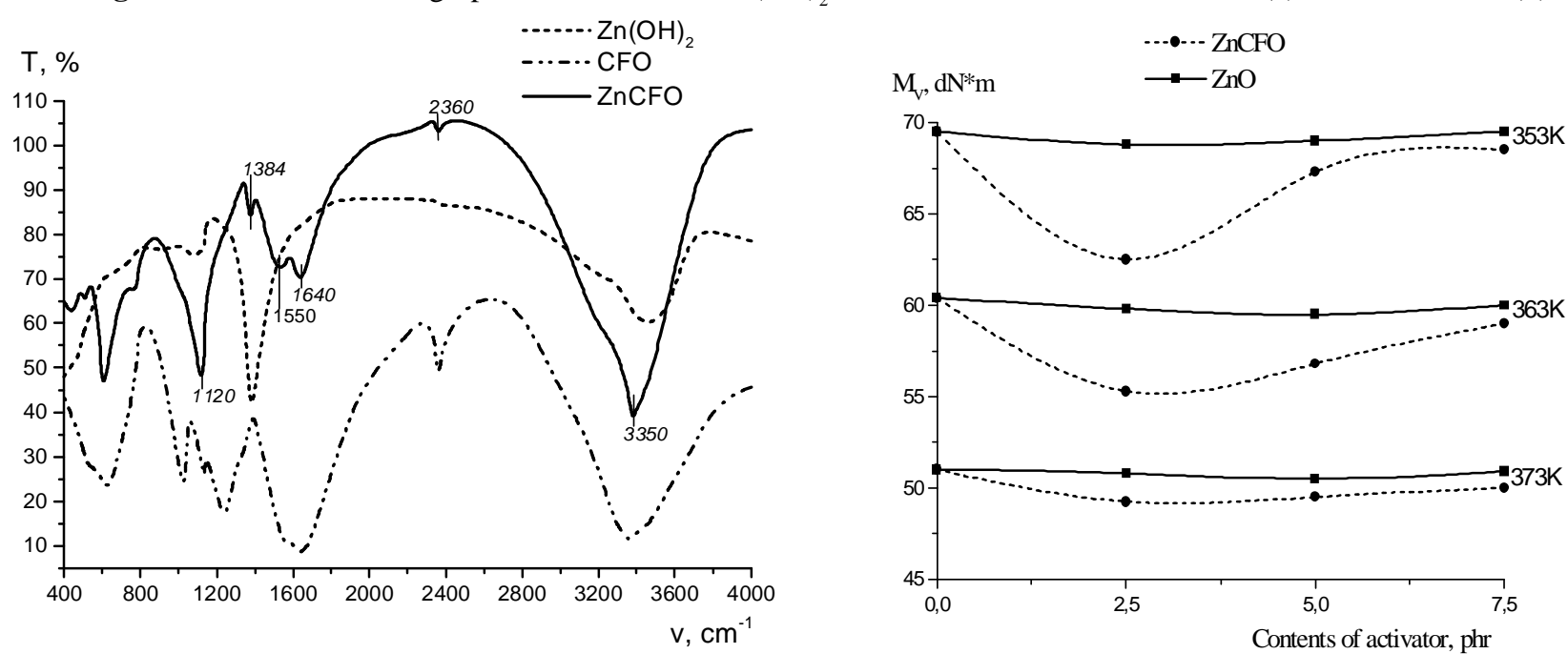

Fig. 3. IR-spectrums of absorption of $\mathrm{ZnCFO}$ and its inorganic $\left(\mathrm{Zn}(\mathrm{OH})_{2}\right)$ and organic $(\mathrm{CFO})$ parts

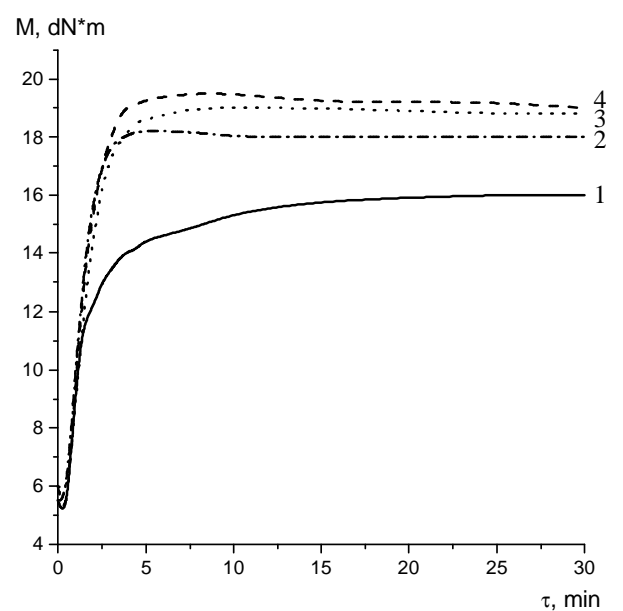

Fig. 5. Rheometer data of sulfur vulcanization process of modeling elastomeric compositions on the basis of isoprene rubber at $428 \mathrm{~K}$ with $\mathrm{ZnCFO}$ as the activator:

$\mathrm{ZnO}-5.0 \mathrm{phr}, k_{2}=0.47 \mathrm{~min}^{-1}(1) ; \mathrm{ZnCFO}-3.0 \mathrm{phr}, k_{2}=0.51$ $\mathrm{min}^{-1}(2) ; \mathrm{ZnO}-5.0 \mathrm{phr}, k_{2}=0.58 \mathrm{~min}^{-1}(3)$ and $\mathrm{ZnO}-7.0 \mathrm{phr}$,

$$
k_{2}=0.69 \mathrm{~min}^{-1}(4)
$$

Fig. 4. Rheological properties of the modeling rubber mixes on the basis of isoprene rubber with a various type and contents of sulfur vulcanization activators

best compatibility in comparison with zinc oxide (Fig. 4). The absence of $\mathrm{ZnCFO}$ particles as extraneous impurities in rubber mix was visually observed, while the zinc oxide particles were clearly visible [7].

Thus, the given results of experimental researches have confirmed compositional and chemically bound structure of $\mathrm{ZnCFO}$ with the presence of functionally active groups, which due to its organic-inorganic nature has determined relationship with rubber matrix, is easily dispersible and combinable with it.

The influence of $\mathrm{ZnCFO}$ concentration (3.0; 5.0 and $7.0 \mathrm{phr}$ ) on formation of properties complex of the unfilled rubber mixes and their vulcanizates on the basis of isoprene rubber of the following composition, phr: isoprene rubber - 100.0; sulfur - 1.0; di-(2-benzothiazolyl) -disulfide - 0.6; N, N'-diphenylguanidine - 3.0; stearic acid - 1.0 was carried out in comparison with the known activator - zinc oxide ( $5.0 \mathrm{phr})$. The analysis of Rheometer data of sulfur vulcanization process of elastomeric 
compositions at $428 \mathrm{~K}$ (Fig. 5) shows that by crosslink density and cure rate, which is proved by the constants of speed in the main period $\left(k_{2}\right)$, they surpass the control composition with $5.0 \mathrm{phr}$ of zinc oxide. Improvement of the complex of elasticity-strength parameters of rubbers with $\mathrm{ZnCFO}$ both at normal test conditions and after thermal air aging (Table 1) is probably caused by the influence of the activator under investigation on vulcanization network character. Thus, the percent part of polysulfide bonds $\left(\mathrm{C}-\mathrm{S}_{\mathrm{x}}-\mathrm{C}\right)$ and amount of sulfur atoms corresponding to one crosslink ( $S$ atoms/crosslink) in vulcanizates with $\mathrm{ZnCFO}$ decreases and the percent part of disulfide bonds (C-S $-\mathrm{C}$ ) increases (Fig. 6).

Thus, the analysis of the received results, has indicated a possibility of equal-mass replacement of the traditional activator - zinc oxide by the polymer under investigation-inorganic composite $(5.0 \mathrm{phr})$ at maintenance of a high activation level of sulfur vulcanization process of rubber mixes on the basis of diene isoprene rubber and improvement of the physical-mechanical properties complex of their vulcanizates.

As zinc oxide can act not only as an activator of sulfur vulcanization of diene rubbers, but also is a required component of other vulcanization systems, the further research of the $\mathrm{ZnCFO}$ effectiveness was carried out in elastomeric compositions on the basis of polar butadiene nitrile rubber of general and special purpose of sulfur, thiuram, and peroxide vulcanization.

The influence of the $\mathrm{ZnCFO}$ contents (3.0; 5.0 and $7.0 \mathrm{phr}$ ) on crosslink kinetics of the modelling unfilled rubber mixes of NBR-26 sulfur, thiuram, and peroxide vulcanization systems of the following composition, phr: NBR-26 - 100.0; sulfur - 1.5; 2-mercaptobenzthiazole - 0.8; stearic acid 1.5; tetramethylthiuramdisulfide -3.0 ; peroximon F-40 3.0, is possible to estimate using the data from Fig. 7. As can be seen, the increase of $\mathrm{ZnCFO}$ concentration results in increase of the maximum torque and, accordingly, crosslink degree of elastomeric compositions, decrease of optimum cure time, which, in turn, causes increase of cure rate, confirmed by the calculated values of relative constant of speed in the main period $\left(k_{2}\right)$. The analysis of vulcanizates physical-mechanical properties proves that with the increase of $\mathrm{ZnCFO}$ contents the increase of the relative tensile strength, hardness, and resilience and the decrease of the relative elongation at break and residual deformation at compression by $20 \%$ are observed. Thus, $\mathrm{ZnCFO}$ is an effective component of the mentioned vulcanization systems, as at equal-mass replacement of the known zinc oxides (5.0 phr) the cure rate and the concentration of crosslink bonds are increased and general properties complex of rubber mixes and their vulcanizates are improved.

The comparative estimation of the effectiveness of similar concentrations of zinc oxides and $\mathrm{ZnCFO}$ (3.0; 5.0 and $7.0 \mathrm{phr}$ ) as the agents of metaloxide vulcanization system was carried out using simulated unfilled elastomeric compositions of chloroprene rubber of the following composition, phr: chloroprene rubber - 100.0; magnesium

Table 1

Properties of the modeling vulcanizates on the basis of isoprene rubber, containing various concentration of the $\mathrm{ZnCFO}$ activator

\begin{tabular}{|l|c|c|c|c|}
\hline \multirow{2}{*}{\multicolumn{1}{|c|}{ Parameter }} & \multicolumn{4}{c|}{ Activator type } \\
\cline { 2 - 5 } & $\mathrm{ZnO}$ & \multicolumn{3}{c|}{ ZnCFO } \\
\cline { 3 - 5 } & $5.0 \mathrm{phr}$ & $3.0 \mathrm{phr}$ & $5.0 \mathrm{phr}$ & $7.0 \mathrm{phr}$ \\
\hline 300\% Modulus, MPa & $10.0 / 9.0$ & $10.0 / 9.0$ & $11.0 / 10.0$ & $10.0 / 9.0$ \\
\hline Tensile strength, MPa & $27.0 / 20.5$ & $26.0 / 22.4$ & $28.5 / 22.8$ & $20.6 / 19.4$ \\
\hline Elongation at break, \% & $890 / 735$ & $830 / 750$ & $835 / 750$ & $835 / 730$ \\
\hline Tear strength, kN/m & $39 / 28$ & $41 / 38$ & $43 / 39$ & $40 / 32$ \\
\hline Shore A hardness & $38 / 35$ & $40 / 36$ & $42 / 38$ & $42 / 38$ \\
\hline Elasticity, \% & $62 / 60$ & $66 / 64$ & $69 / 65$ & $68 / 64$ \\
\hline
\end{tabular}

*in the denominator the parameter value after thermal aging of the sample at $373 \mathrm{~K}$ and $24 \mathrm{~h}$ is given

Table 2

Properties of modeling elastomeric compositions on the basis of chloroprene rubber in vulcanization optimum

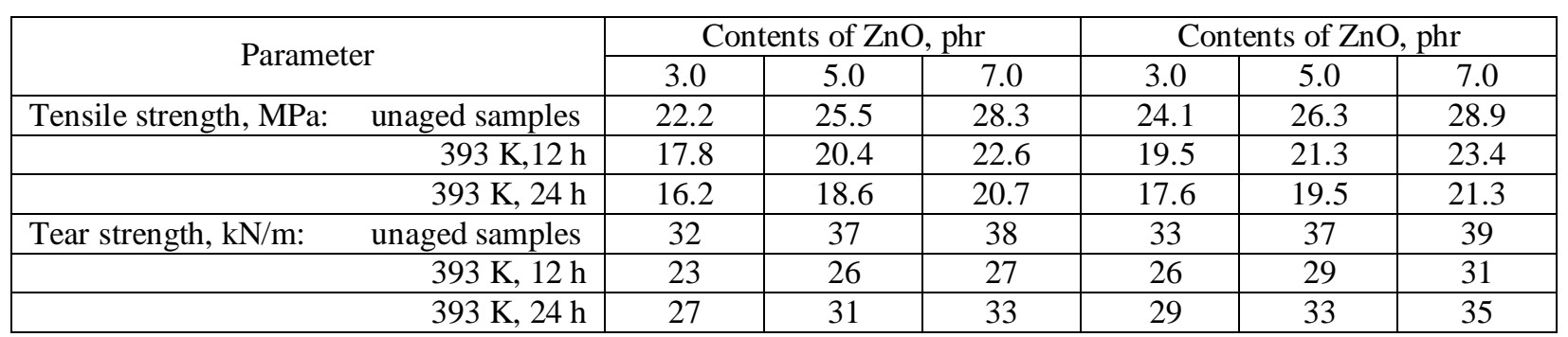


$\mathrm{ZnO}$ as activator of sulfur vulcanization system

$S_{\text {atoms }} /$ crosslink $=7,6$

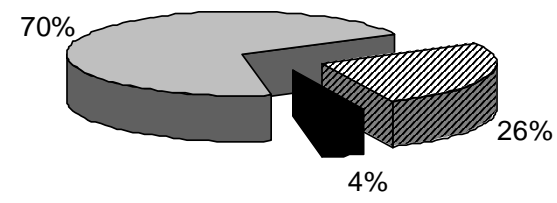

ZnCFO as activator of sulfur vulcanization system

$S_{\text {atoms }} /$ crosslink $=7,3$

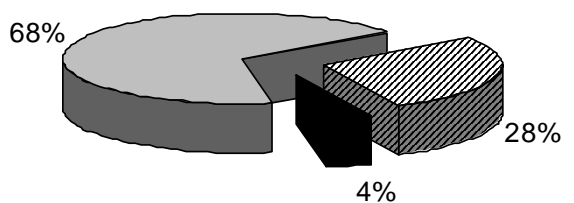

Fig. 6. Influence of activator type on vulcanization network character of the elastomeric compositions:

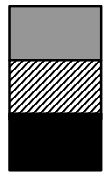

$$
\begin{aligned}
& -\% \text { part of } \mathrm{C}-\mathrm{S}_{\mathrm{x}}-\mathrm{C} \text { bonds; } \\
& -\% \text { part of } \mathrm{C}-\mathrm{S}_{2}-\mathrm{C} \text { bonds; } \\
& -\% \text { part of } \mathrm{C}-\mathrm{S}-\mathrm{C} \text { bonds. }
\end{aligned}
$$

oxide - 7.0. Kinetic curves of rubber mixes cross-linking process at $428 \mathrm{~K}$ are shown in Fig. 8. The analysis of the obtained data indicates that at increase of zinc oxide contents vulcanization kinetics is changed as follows: the induction period and optimum cure time decrease while the cure rate increases. Vulcanization process of rubber mixes in the presence of $\mathrm{ZnCFO}$ proceeds similarly; however, its crosslink degree parameter is by $15-22 \%$ higher than in the compositions with zinc oxides. The estimation of elasticitystrength properties of rubbers in vulcanization optimum has shown that $\mathrm{ZnCFO}$ provides higher parameters level and resistance to thermal air aging (Table 2).

For further research of $\mathrm{ZnCFO}$ effectiveness in the structure of various vulcanization systems its was entered into the rubber mix on the basis of butyl rubber of resin vulcanization of the following composition, phr: butyl rubber-1675 - 100.0; amberol ST-137 - 5.0; stearic acid - 3.0; 3.0 zinc oxide phr being replaced by 3.0; 5.0 and $7.0 \mathrm{phr}$ of $\mathrm{ZnCFO}$. The influence of $\mathrm{ZnCFO}$ on the kinetics of resin vulcanization at $433 \mathrm{~K}$ is shown in Fig. 9, which indicates that in comparison with the control mix the researched compositions are characterized by the decrease of the relative crosslink degree, retention of scorch time and reduction of optimum cure time, causing the increase of cure rate, i.e. at $\mathrm{ZnCFO}$ use as a component of resin vulcanization the acceleration of the formation process of crosslinking network with low density of crosslink bonds is observed, which explains the unsatisfactory level of physical-mechanical parameters of the rubber. The negative influence of $\mathrm{ZnCFO}$ on the properties of elastomeric compositions of resin vulcanization is caused by interaction between the vulcanization agent (phenolformaldehyde resin on the basis of p-octylphenol - ST137) and $\mathrm{ZnCFO,} \mathrm{which} \mathrm{results} \mathrm{in} \mathrm{desactivation} \mathrm{of} \mathrm{resin}$ as crosslinking agent of resin vulcanization system.

Thus, from the analysis of the results of experimental researches on estimation of $\mathrm{ZnCFO}$ vulcanization activity in comparison with zinc oxide in the structure of various vulcanization systems (VS) it follows, that its effectiveness decreases in the series (Fig. 10):

sulfur VS $>$ thiuram VS $>$ metaloxide VS $>$ peroxide VS

$$
>\text { resin VS }
$$

Taking into account the positive influence of $\mathrm{ZnCFO}$ on the formation of the complex of the physicalmechanical characteristics of vulcanizates on the basis of various rubbers and theoretical preconditions of the "composition-structure-properties" interrelation, it was of interest to define the morphology features of elastomeric compositions. With this purpose the percalation method of the analysis by the rheometer data of rubber mixes was used [9].

According to the theory of "composition-structureproperties" interrelation the maximum level of the physicalmechanical characteristics of elastomeric compositions is reached under condition of heterogeneous structure formation with the minimal particles size of heterophase ( $r$ - value, opposite to tangent of the corner of kinetics curve inclination) and its optimum contents. The analysis of the data presented in Fig. 11 shows, that replacement of zinc oxide by $\mathrm{ZnCFO}$ composite in various vulcanization systems for rubbers of general and special purpose influences morphological structure of compositions, reducing the particles size of heterophase and thereby providing thus high complex of the elasticity-strength properties of vulcanizates. It is necessary to note, that at the increase of the $\mathrm{ZnCFO}$ contents from 5.0 up to 7.0 phr parameter $r$ is not essentially changed and retains the minimal value, i.e. the best complex of properties have the compositions with $\mathrm{ZnCFO}$, in which the morphology with the minimal particles size of heterophase is formed at its contents $\approx 5.0 \mathrm{phr}$. The given statement corresponds with the experimentally obtained results of physicalmechanical tests of vulcanizates.

The decrease of $\mathrm{ZnCFO}$ effectiveness as component of various vulcanization systems for rubbers of general and special purpose in the above presented series (Fig. 10) can be also explained by the character of the formed morphology of compositions. Thus, at use of $\mathrm{ZnCFO}$ as the activator of sulfur vulcanization the structure of rubbers with the minimal value of parameter $r$ is formed, and at transition from sulfur to peroxide 


\section{Sulfur vulcanization system}

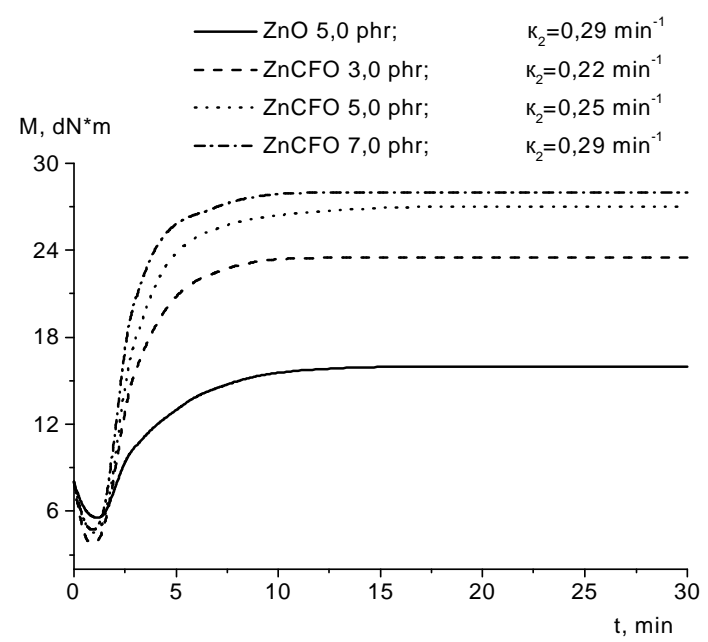

Thiuram vulcanization system

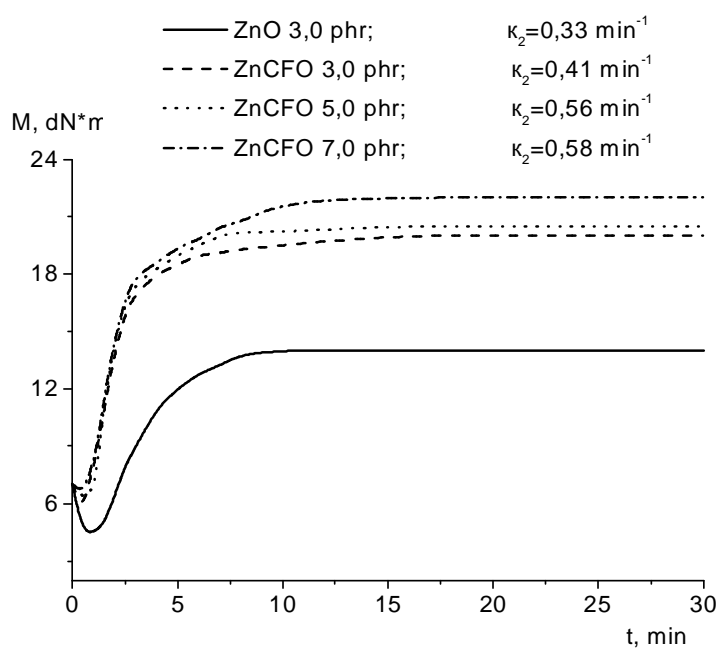

Peroxide vulcanization system

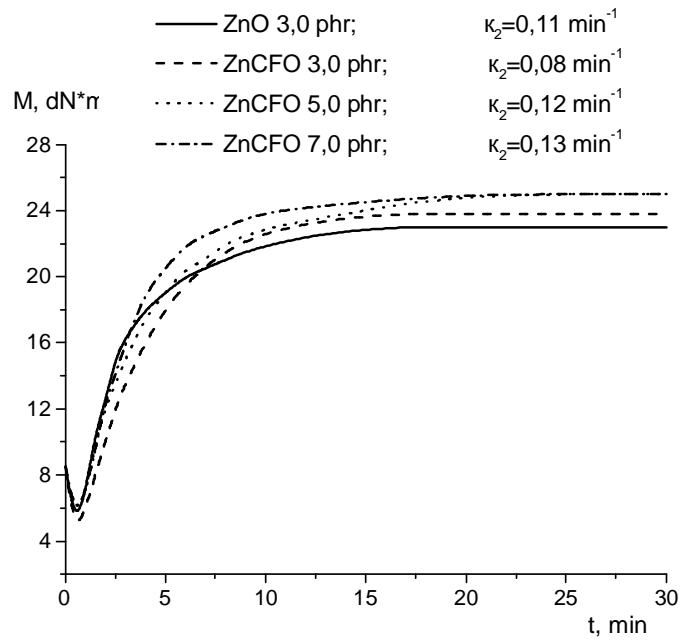

Fig. 7. Cure curves of vulcanization process of modeling elastomeric compositions on the basis of nitrile-butadiene rubber at $428 \mathrm{~K}$ with various vulcanization systems

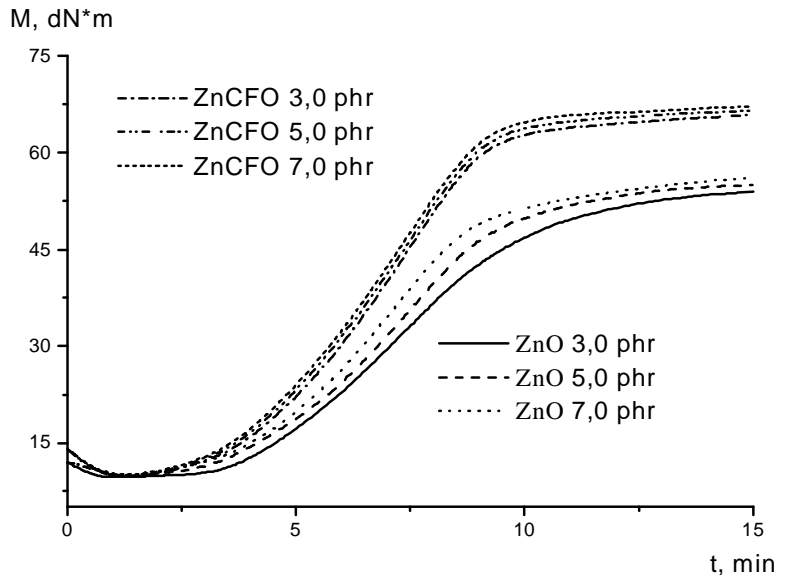

Fig. 8. Cure curves of metaloxide vulcanization process of modeling elastomeric compositions on the basis of chloroprene rubber at $428 \mathrm{~K}$ with various type and contents of vulcanization agents

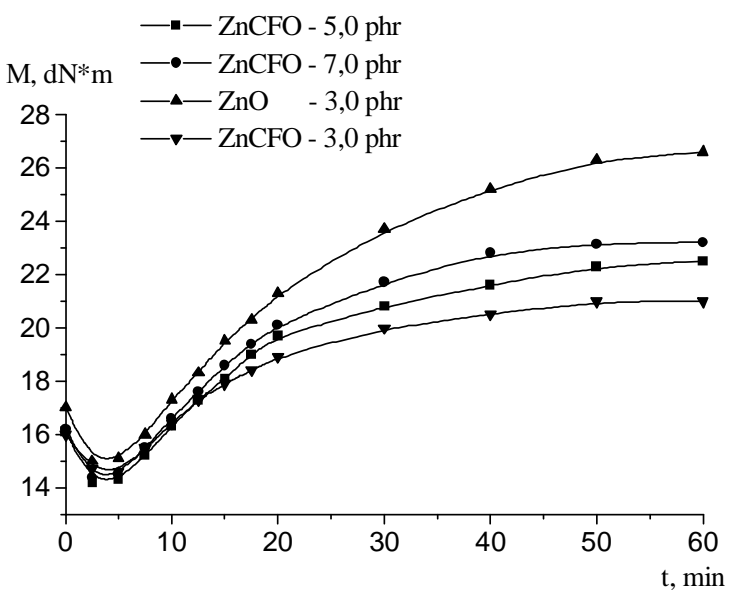

Fig. 9. Vulcanization kinetics of modeling elastomeric compositions on the basis of butyl rubber of resin vulcanization at $433 \mathrm{~K}$ with $\mathrm{ZnO}$ or $\mathrm{ZnCFO}$ $\%$

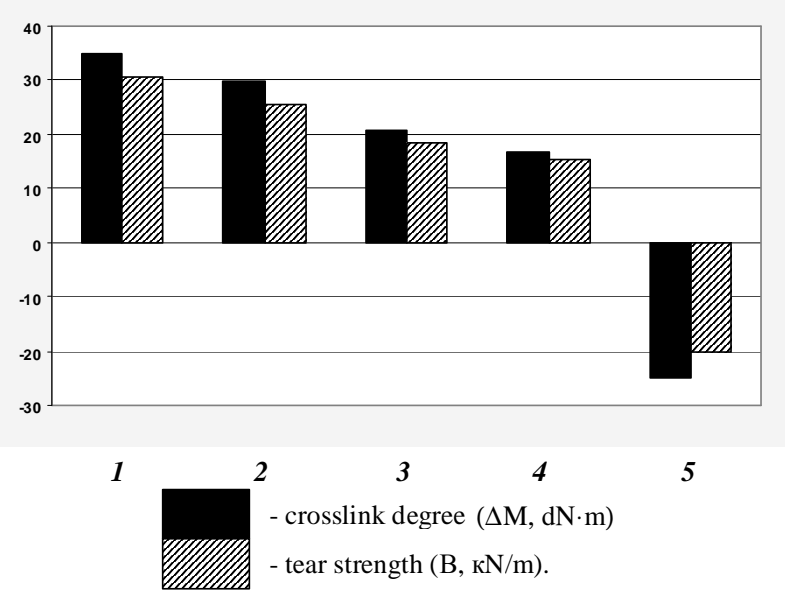

Fig. 10. Change of elastomeric compositions properties (\%) with various vulcanization systems (VS) at ZnCFO presence (in comparison with $\mathrm{ZnO}$ ): sulfur VS (1); thiuram VS (2); metaloxide VS (3); peroxide VS (4) and resin VS (5) 
vulcanization of elastomeric compositions the heterophase particles size increases (Fig. 11b).

\section{Conclusions}

Based on the results of the researches of the $\mathrm{ZnCFO}$ effectiveness as the component of various vulcanization systems for rubbers of general and special purpose, it is possible to make the following conclusions:

1. $\mathrm{ZnCFO}$ is a chemically connected composite with functionally active groups, which due to its organicinorganic nature is easily dispersed and combined with rubber matrix.

2. $\mathrm{ZnCFO}$ is an effective component of sulfur, thiuram, peroxide and metaloxide vulcanization systems for isoprene, nitrile-butadiene and chloroprene rubbers; at the same time it is not effective in resin vulcanization system for butyl rubber. By the positive influence degree
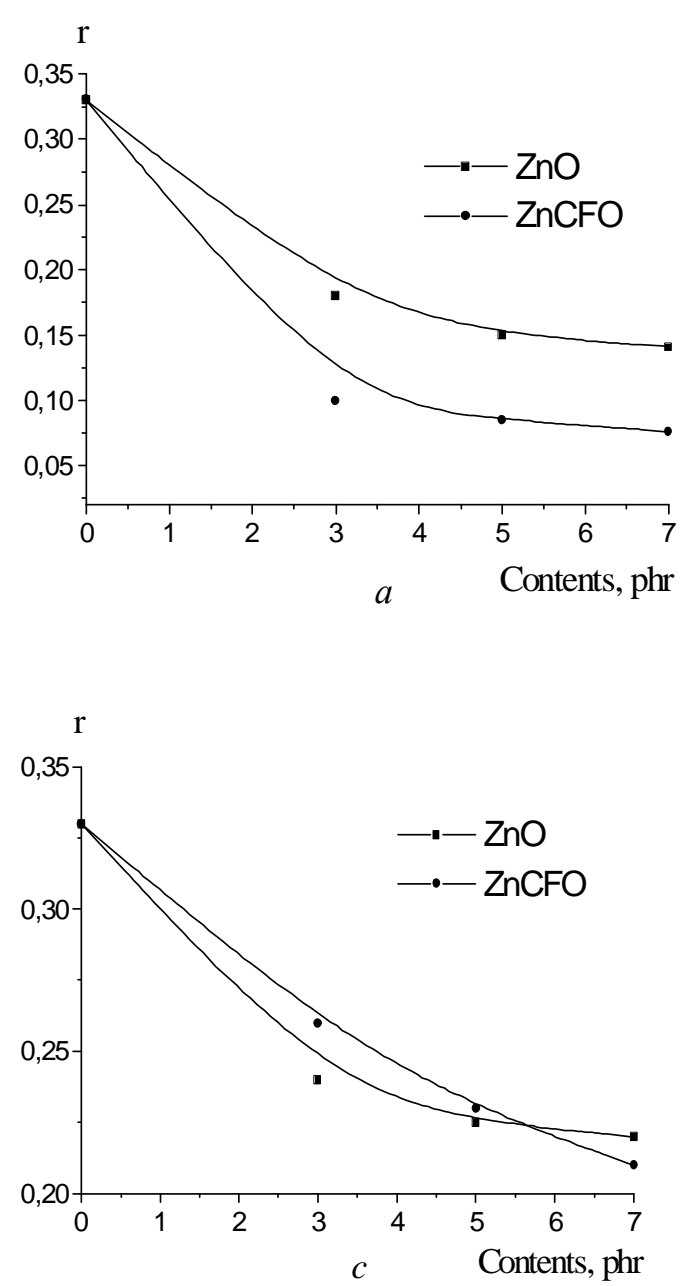

on the properties of elastomeric compositions vulcanization systems with $\mathrm{ZnCFO}$ are arranged in a series: sulfur VS > thiuram VS > metaloxide VS > peroxide VS

3. ZnCFO at the contents H" 5.0 phr promotes the formation of morphological structure of compositions with the minimal particles size of heterophase, which results in the improvement of physical-mechanical properties of rubbers.

\section{Acknowledgements}

The authors express their thanks to professor E. Djagarova (University of Chemical Technology and Metallurgy, Sofia, Bulgaria) for assistance in organization and conducting of experimental researches of estimation of rubber mixes rheological properties, and to professor W. M. Rzymski (Technical University, Lodz, Poland) for determination of sulfidity of vulcanizates crosslinks.
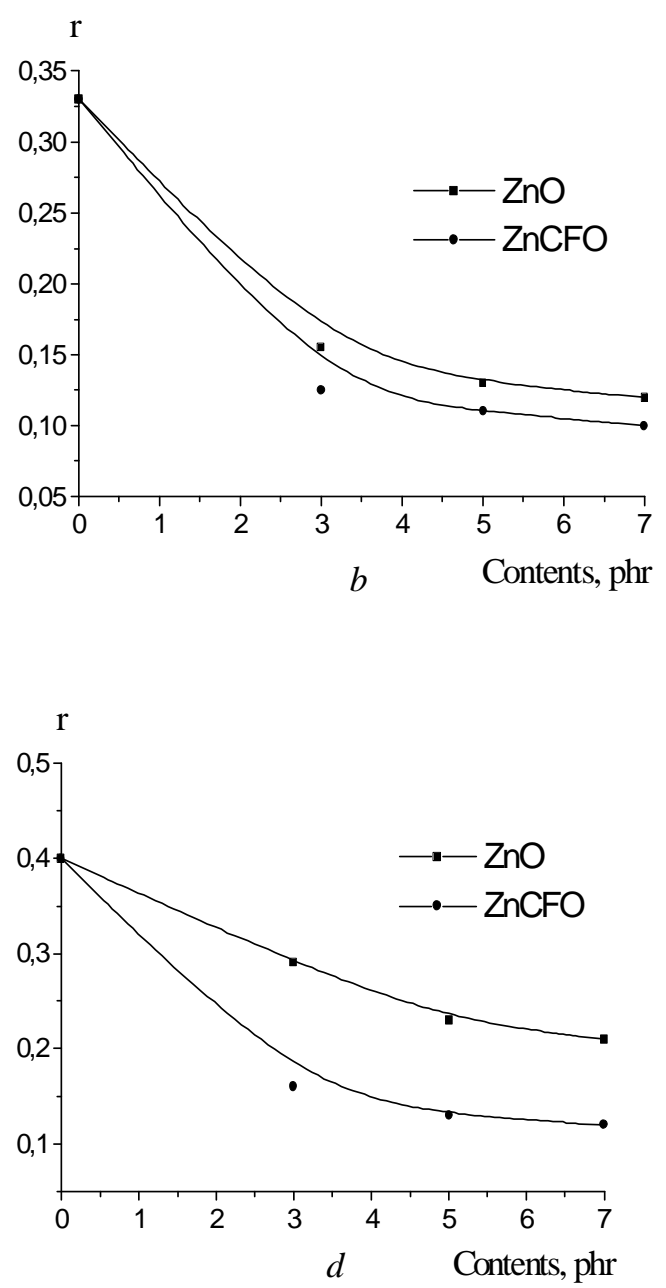

Fig. 11. Dependence of particles size of heterophase of modeling compositions on the basis of various rubbers with different vulcanization systems from the $\mathrm{ZnO}$ or $\mathrm{ZnCFO}$ contents: nitrile-butadiene rubber of sulfur vulcanization (a); nitrile-butadiene rubber of thiuram vulcanization (b); nitrile-butadiene rubber of peroxide vulcanization (c) and chloroprene rubber of metaloxide vulcanization $(\mathrm{d})$ 


\section{References}

[1] Melnikov B., Perekhrest O., Demidov D. and Machula S.: Khim. Promyslovist Ukrainy, 2000, 3, 32.

[2] Kachkurkina I., Ovcharov V. and Okhtina O.: Voprosy Khimii i Khim. Techn., 2005, 5, 134.

[3] Uendland U.: Termicheskie metody analyza. Mir, Moskwa 1978.

[4] Slowikowskiya I.: Cwiczenia laboratoryjne z chemii i technologii polimerow. Ofycyna Wydawnicza Politechniki Warszawskiej, Warszawa 1997.

[5] Kalinina L.: Kachestvenniy analyz polimerov. Khimiya, Moskwa 1975.

[6] Gordon A. and Ford R.: Sputnik khimika. Mir, Moskwa 1976.

[7] Djagarova E., Jeveleva D. and Zdravkov Z.: J. Univ. Chem. Techn. Metall., 2002, 3, 71.

[9] Gavriluk N.: Khim. Promyslovist Ukrainy, 1996, 4, 37.

\section{ОСОБЛИВОСТІ ВУЛКАНІЗАЦЇ̈ КАУЧУКІВ ЗАГАЛЬНОГО ТА СПЕЦАЛЬНОГО ПРИЗНАЧЕННЯ У ПРИСУТНОСТІЦИНКВМІСНОГОПОЛІМЕР- НЕОРГАНІЧНОГОКОМПОЗИТУ}

Анотація. У роботі описана нова технологія синтезу цинквмісного полімер-неорганічного композиту (ZnCFO), структура та властивості якого вивчені за допомогою ряду інструментальних методів аналізу. Досліджено дію ZnCFO як вулканізаційно-активного інградієнта еластомерних композичій на основі каучуків загального та спеціального призначення різних систем вулканізаиії. Методом перкаляиійного аналізу визначений вплив ZnCFO на характер морфологічної структури синтезованих гум.

Ключові слова: ичинквмісний полімер-неорганічний композит, каучук, вулканізація, еластомерна композиція, активатор вулканізації, фізико-механічні властивості, морфологічна структура. 